\title{
Antimicrobial activity of Imidazolidinyl urea
}

\section{Eiji Nakano}

Antimicrobial activity of Imidazolidinyl urea (IU) is tested in $M / 10$ phosphate buffer solutions against two strains; Escherichia coli and Pseudomonas aeruginosa. The influences of pH, gelatin and collagen hydrolysate on its activity are also tested respectively; the following results are obtained.

Antimicrobial activity of Imidazolidinyl urea (IU) has a tendency to be more effective in alkaline $\mathrm{pH}$ range.

Imidazolidinyl urea (IU) is slightly inactivated in the presence of gelatin.

But its activity is more effectively decreased in collagen hydrolysate solution, especially in the case of Pseudomonas aeruginosa. In this collagen hydrolysate solution, the growth of two microbes is less inhibited in alkaline $\mathrm{pH}$ range than in acid one.

Weak phototoxity of Imidazolidinyl urea (IU) against Escherichia coli is recognized by irradiation of $290-350 \mathrm{~nm}$ ray.

\section{1 緒 言}

イミダゾリジニルウレア (IU)・は，かなり広い抗菌ス ペクトルをもつ抗菌剤として欧米では化粧品に使用され ているが，わが国での使用はまだ許可されていない。著 者は, 本抗菌剤の化学構造が, 従来化粧品に用いられて きた抗菌剤とかなり異なっているらえに，1．無味無臭 であり，微生物の増殖する水相への溶解度が大きいこ と，2.ラット等の実験動物に対する毒性が小ざいごと, 等の報告がなされている1。そこで本品の抗菌剤として の有用性が期待されるので，その抗菌性について若干の 試験を行なった。

一般に抗菌剤の抗菌力は, 1. 微生物の種類 $2 . \mathrm{pH} 3$. 共存物質, 等により変動し, 3.については特に蛋白質の 共存で抗菌力が低下することが知られている。そこで IU に対するこれらの影響を調べるために, 試験菌株と しては化粧品の代表的な污染菌である E. coli ならび

株式会社ピアス研究所

大阪市大淀区豊崎町西通 $1-18$

Research Laboratory of Pias Co., Ltd.

18, Toyosaki Nishidori 1-chome, Oyodo-ku, Osaka
に Ps. aeruginosa の 2 菌株, pH は 4.0 10.0, 共存 物質としてゼラチンおよびュラーゲン加水分解物を使用 し，各組み合わせによる抗菌力試験を行なった。また E. coli に対する光毒性試験も行なったので併せて報告 する。

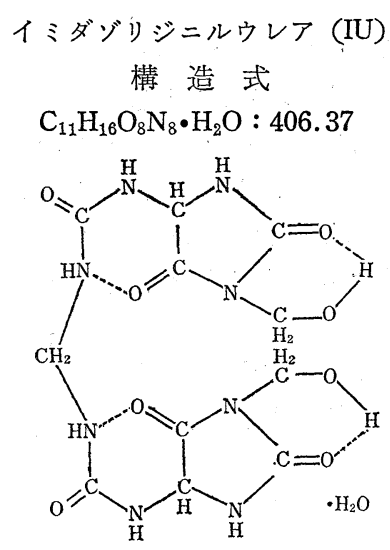

\section{2 実験材料及び方法}

\section{2 - 1 抗菌力試験}

試験菌株の E. coli. Ps. aeruginosa は, tryptic soy 
broth 中で $30^{\circ} \mathrm{C}, 24$ 時間培養したものを用いた。

$\mathrm{pH}$ は $\mathrm{M} / 10$ リン酸緩衝液で, $\mathrm{pH} 4.0,5.5,7.0,8.5$, 10.0 の 5 段階に調整した。ゼラチンはバクトゼラチン

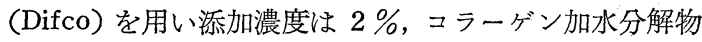
注1）は抗菌剤を含まないものを用い添加濃度は $5 \%$ と した。

注 1 ）コラーゲン蛋白質を加水分解して得られるポリ ペプタイドとアミノ酸混合物のナトリウム塩 40４4\% 及び $\mathrm{NaCl} 8 \%$ を含む水溶液（成和化成）

試験液の調製 : 各試料の滅菌は次のように行なった。 リン酸緩衝液及びゼラチン，コラーゲン加水分解物は水 溶液として，それぞれ別々に， $120^{\circ} \mathrm{C}, 10$ 分間，オート クレーブで滅菌した。

$\mathrm{IU}$ は水溶液とし，沪過除菌を行なった。

試験液は，(1) $\mathrm{M} / 10$ リ. 酸緩衝液 $(\mathrm{pH} 4.0,5.5,7.0$, $8.5,10.0$ ) に IUを $0.025 \%$ 及び $0.1 \%$ 含むもの，(2)

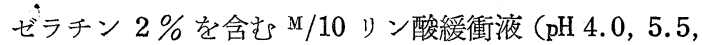
$7.0,8.5,10.0)$ に IU を $0.025 \%$ 及び $0.1 \%$ 含むも の, (3)コラーゲン加水分解物 $5 \%$ を含む $\mathrm{M} / 10$ リン酸緩 衝液（pH 4.0, 5.5, 7.0, 8.5, 10.0）に IU を $0.025 \%$ 及び $0.1 \%$ 含むもの, であり，上記の滅菌試料を適宜 混合して調製した。

これらの試験液に, 試験菌株の培湌液を希釈して初発 菌数が約 $10^{5} / \mathrm{ml}$ になるように加光, 直径 $30 \mathrm{~mm}$ の試験 管に入れ， $30^{\circ} \mathrm{C}$ で静置培養した。 5 時間， 24 時間， 3 日，8 日後に試料を採取し，普通寒天培地による混釈法 で $30^{\circ} \mathrm{C}, 48$ 時間後に形成されるコロニー数より生菌数 を算出した。

\section{2 ・ 2 E. coli に対する光毒性試験}

tryptic soy broth 中で $30^{\circ} \mathrm{C}, 24$ 時間培養した E. coli を， 5000 r. p. m. で5 分間遠心分離し， $\mathrm{pH} 7.2$ の PBS 溶液で 2 度洗浄，同液に約 $10^{5} / \mathrm{m} \ell$ になるように 懸濁する。この懸濁液に，沪過除菌した IU の PBS 溶 液を加えて所定の濃度 $(0.01 \%, 0.1 \%)$ に調整し，10分 間室温に保持する。内径 $6 \mathrm{~cm}$ のシャーレにこの試験液 $5 \mathrm{ml}$ 分分注し, 20W 東芝 FL20SE（波長分布 290 350 $\mathrm{nm}$. ピーク波長 $320 \mathrm{~nm}$ 付近) 及び東芝 FL20S-BLB

(300 400nm. ピーク波長 $350 \mathrm{~nm}$ 付近) を $14 \mathrm{~cm}$ の距 離から直接照射する。照射時間を変えて試料を採取し普 通寒天培地による混釈法で $30^{\circ} \mathrm{C}, 48$ 時間後に形成され るコロニ一数より生菌数を算出し, 照射線量一生存率曲 線を求めた。

\section{3 結 果}

\section{3・ 1 抗菌力試験}

$3 \cdot 1 \cdot 1$ リン酸緩衡液における IU の抗菌力

IU 無添加のリン酸緩衝液中での試験菌株の生育曲線 を Fig. 1，2 に示す。これらの図に扔いて初発菌数約 $10^{5} / \mathrm{m} \ell$ を 1 とし, 生菌数の増減を比率で示した。以下 の図について呞様である。 E. coli の生育至適 $\mathrm{pH}$ は Fig. 1 に示通り 5.5 7.0 であり, $\mathrm{pH} 4.0$ 及び 10.0 では生育が不可能である。一方 Ps. aeruginosa の生育 至適pHは Fig.2 に示す通り 5.5 8.5 であり， pH 4.0 で は生育が不可能である。

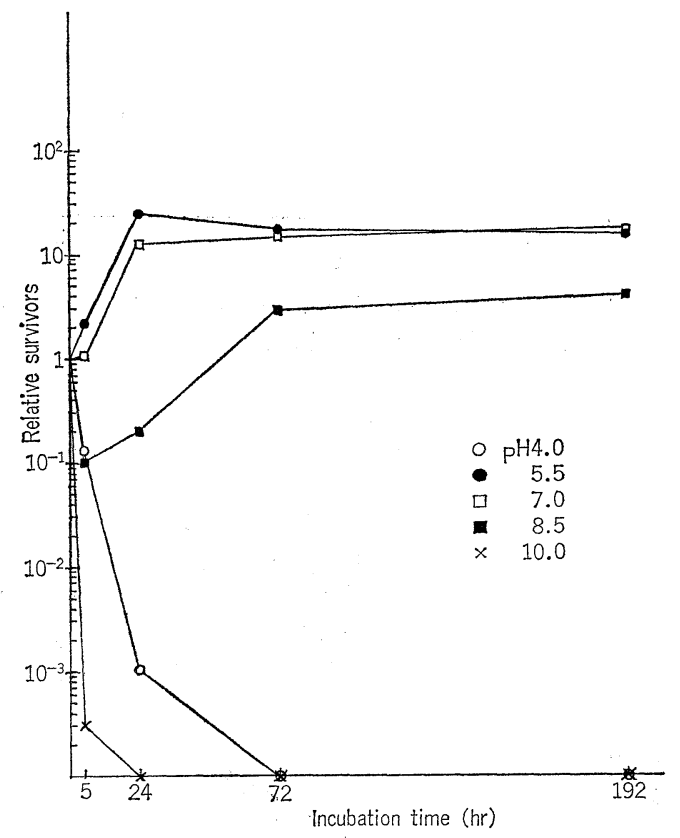

Fig. 1 Growth curves of E. coli in $M / 10$ phosphate buffer solutions

このリン酸緩衝液中での IU の両菌株に対する抗菌力 は，0.025\% で Fig. 3 に示す通り E. coli に対して, $\mathrm{pH} 7.0 \sim 8.5$, Ps. aeruginosa に対して $\mathrm{pH} 7.0 \sim 10.0$, でかなり大きい。しかし $\mathrm{pH} 5.5$ では，両菌株に対する 抗菌力は小さい。IU の $0.1 \%$ 濃度では Fig. 4 に示す 通り，すべての $\mathrm{pH}$ 域で十分な抗菌力を示した。

すなわち IU の両囷株に対する抗菌力は, $\mathrm{pH} 5.5$ で小 さく $\mathrm{pH} 7.0$ 以上では大きい。

$3 ・ 1 ・ 2$ ゼラチン $2 \%$ 添加リン酸緩衝液における IU の抗菌力

ゼラチン添加リン酸緩衝液中での試験菌株の生育至適 


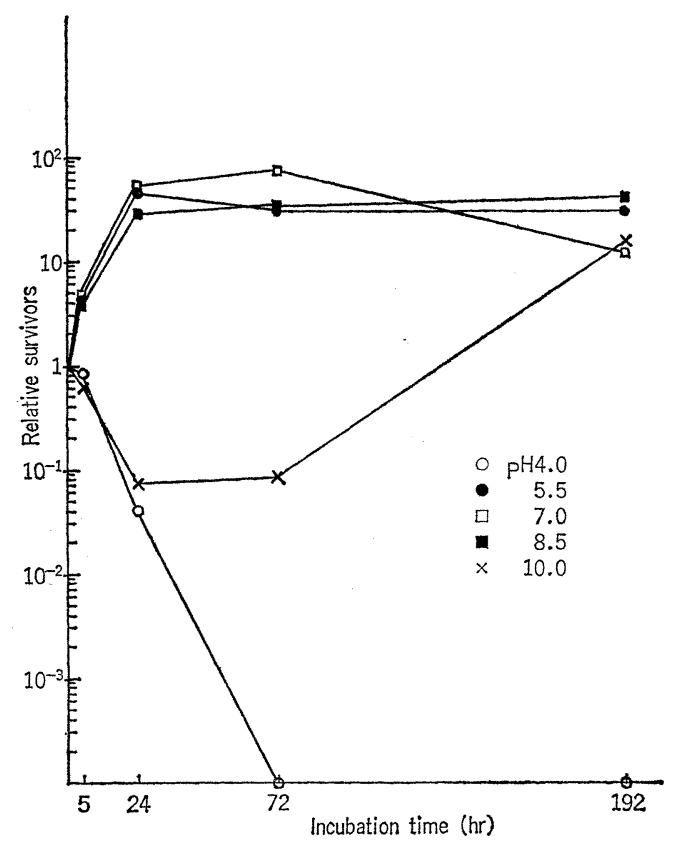

Fig. 2 Growth curves of Ps. aeruginosa in $\mathrm{M} / 10 \mathrm{ph}-$ osphate buffer solutions

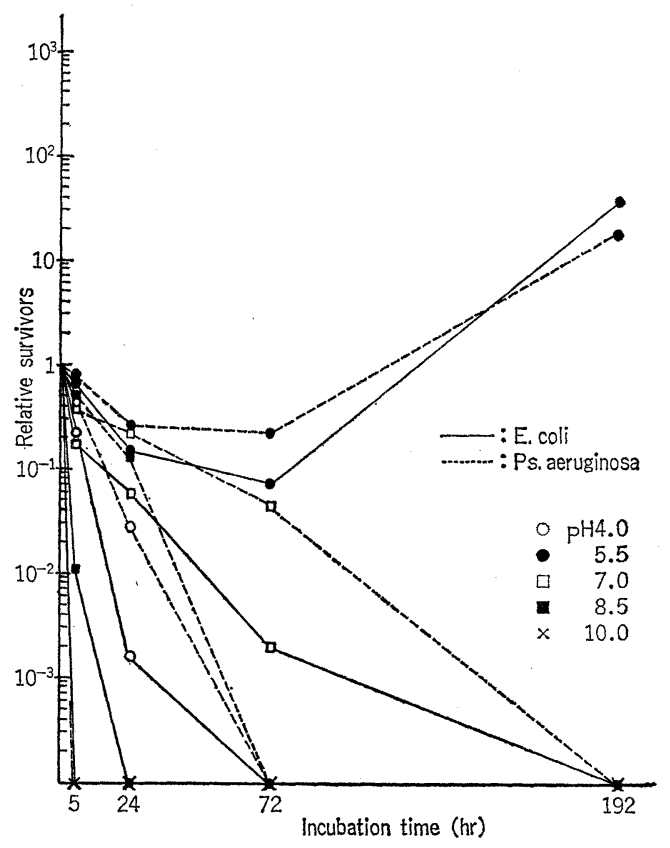

Fig. 3 Growth curves of E. coli and Ps. aeruginosa in $\mathrm{M} / 10$ phosphate buffer solutions containing $0.025 \%$ of IU

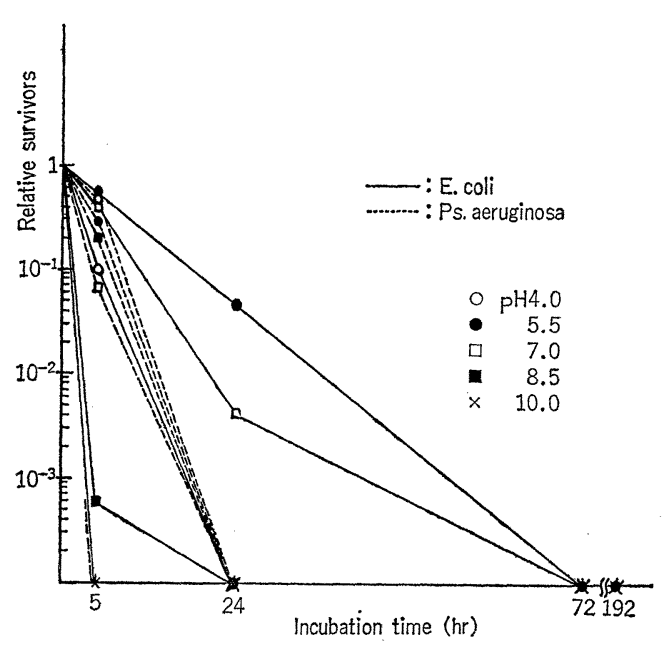

Fig. 4 Growth curves of E. coli and Ps. aeruginosa in $\mathrm{M} / 10$ phosphate buffer solutions containing $0.1 \%$ of IU

$\mathrm{pH}$ は, Fig. 5 に示す通り E. coli で 5.5 8.5 であ り, ゼラチン無添加の場合よりも広くなる。Ps. aeruginosa \& Fig. 6 に示す通り生育至適 $\mathrm{pH}$ が E. coli の 場合と同範囲にあり, $\mathrm{pH} 10.0$ でもかなり増殖する。

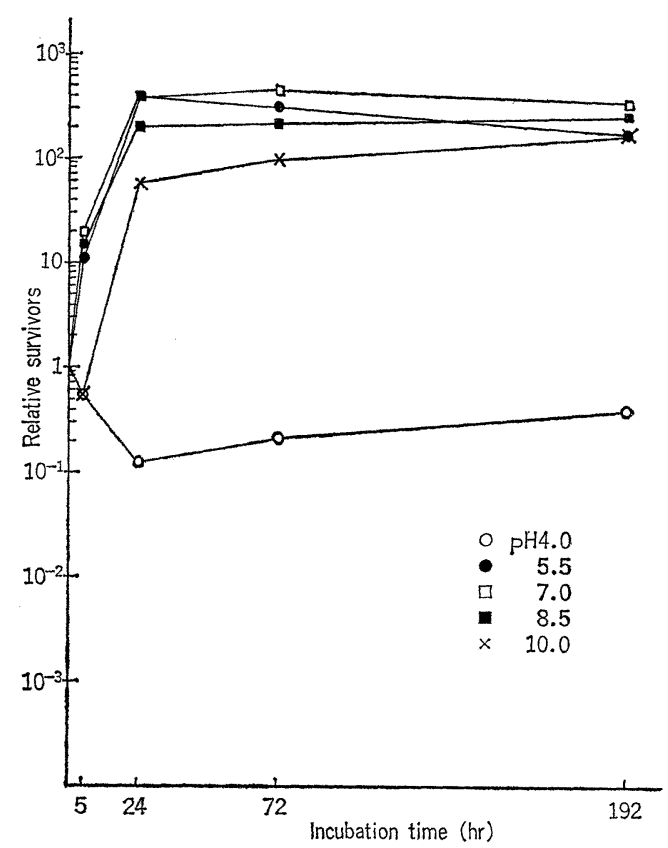

Fig. 5 Growth curves of $\mathrm{E}$. coli in $\mathrm{M} / 10$ phosphate buffer solutions containing $2 \%$ of gelatin 


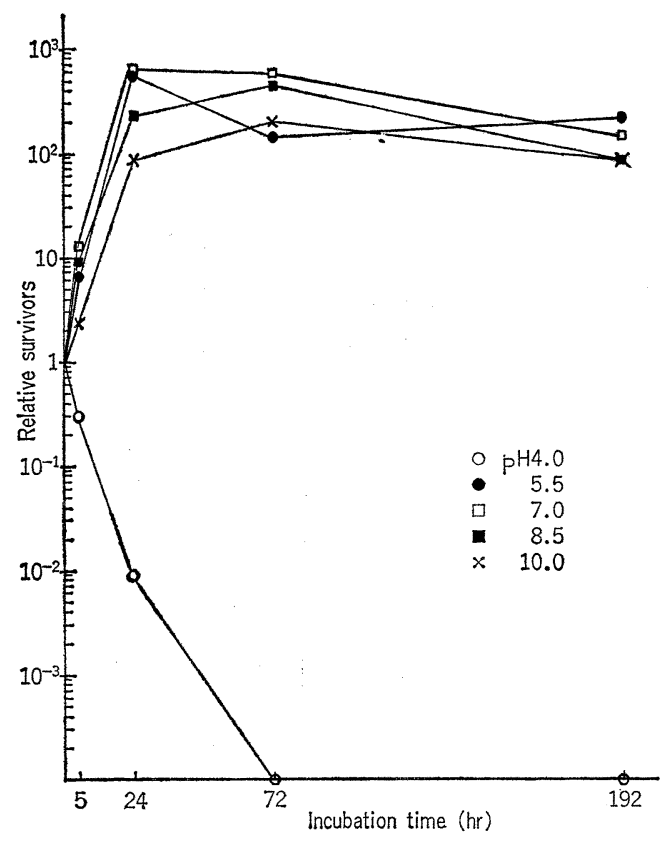

Fig. 6 Growth curves of Ps. aeruginosa in M/10 phosphate buffer solutions containing $2 \%$ of gelatin

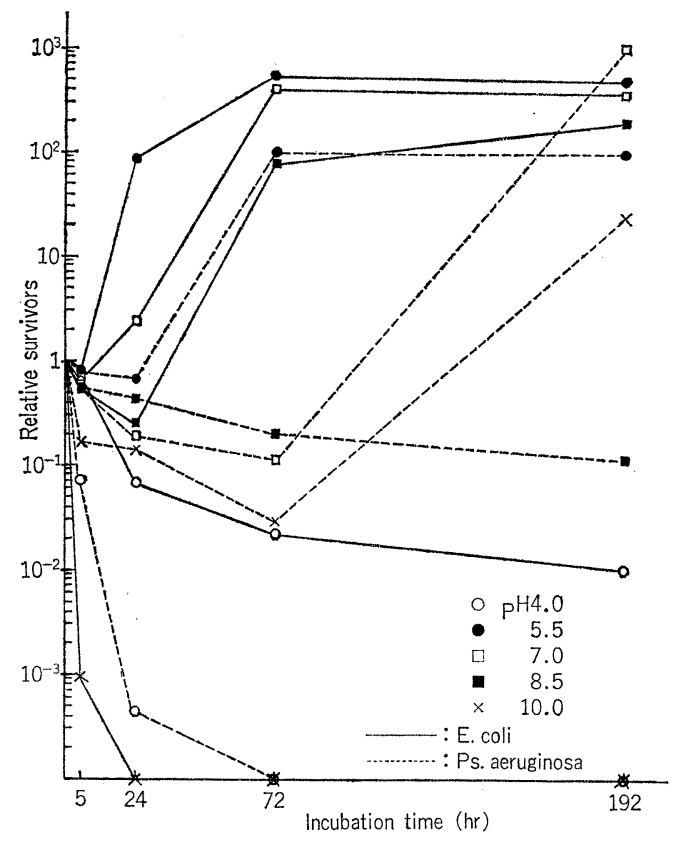

Fig. 7 Growth curves of E. coli and Ps. aeruginosa in $\mathrm{M} / 10$ phosphate buffer solutions containing $0.025 \%$ of IU and $2 \%$ of gelatin

この試験液に IU を添加した場合の結果を Fig. 7, 8
に示す。 $0.025 \%$ 濃度ではわずかな抗菌力を示す程度で あるが， $0.1 \%$ 濃度では十分な抗菌力を示した。ただ $\mathrm{pH}$ 5.5 に比較して $\mathrm{pH} 7.0$ 以上のアルカり側での抗菌力が 大きい傾向がみられる。

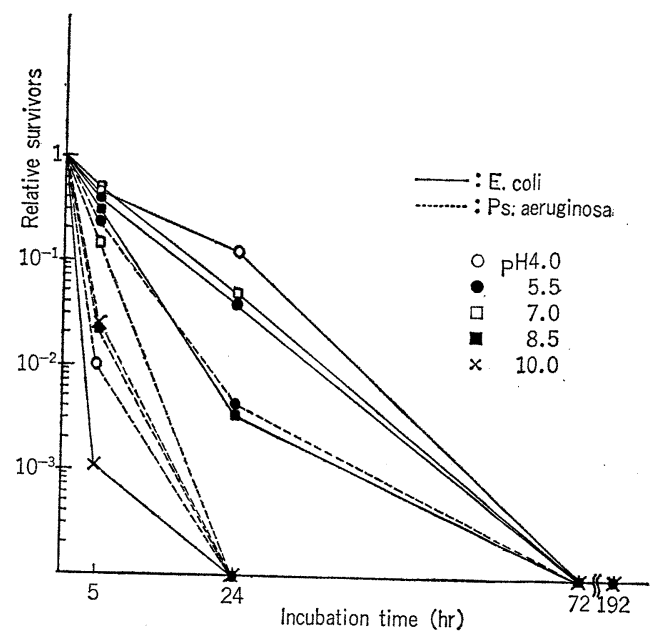

Fig. 8 Growth curves of E. coli and Ps. aeruginosa in $\mathrm{M} / 10$ phosphate buffer solutions containing: $0.1 \%$ of IU and $2 \%$ of gelatin

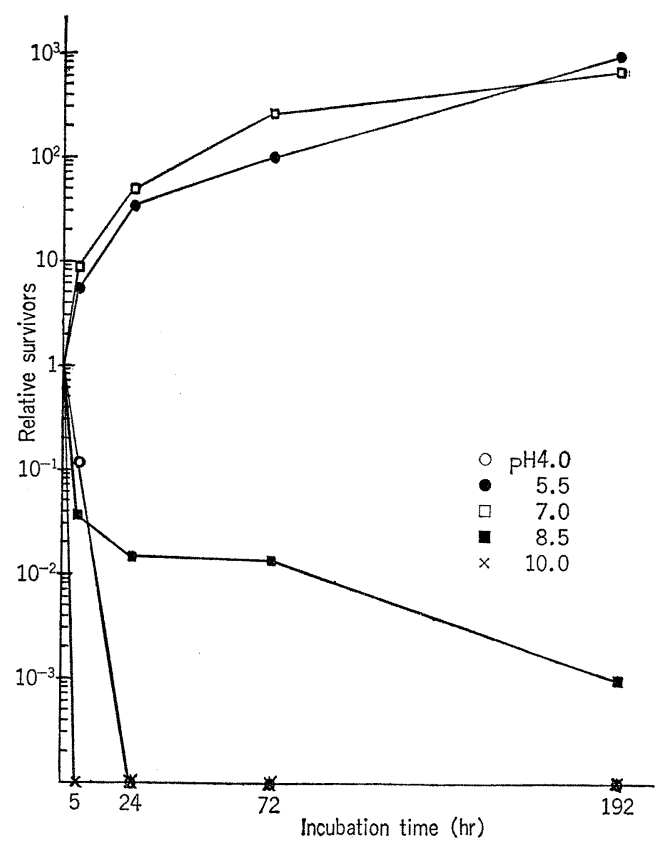

Fig. 9 Growth curves of $\mathrm{E}$. coli in $\mathrm{M} / 10$ phosphate buffer solutions containing $5 \%$ of collagen hydrolysate 
$3 ・ 1 ・ 3$ コラーダン加水分解物 $5 \%$ 添加リン酸緩衝 液に打ける IU. の抗菌力

コラーゲン加水分解物添加リン酸緩衝液中での生育曲 線を Fig. 9，10 に示す。E. coli の生育至適 $\mathrm{pH}$ はFig. 9 に示すように 5.5 7.0 でありコラーゲン加水分解物 無添加の場合と変わらない。一方 Ps. aeruginosa の生 育至適 $\mathrm{pH}$ は, Fig. 10 に示すように 7.0〜10.0 であり, コラーゲン加水分解物無添加の場合に比較してアルカリ 側に拡がり $\mathrm{pH} 5.5$ では増殖はみられない。

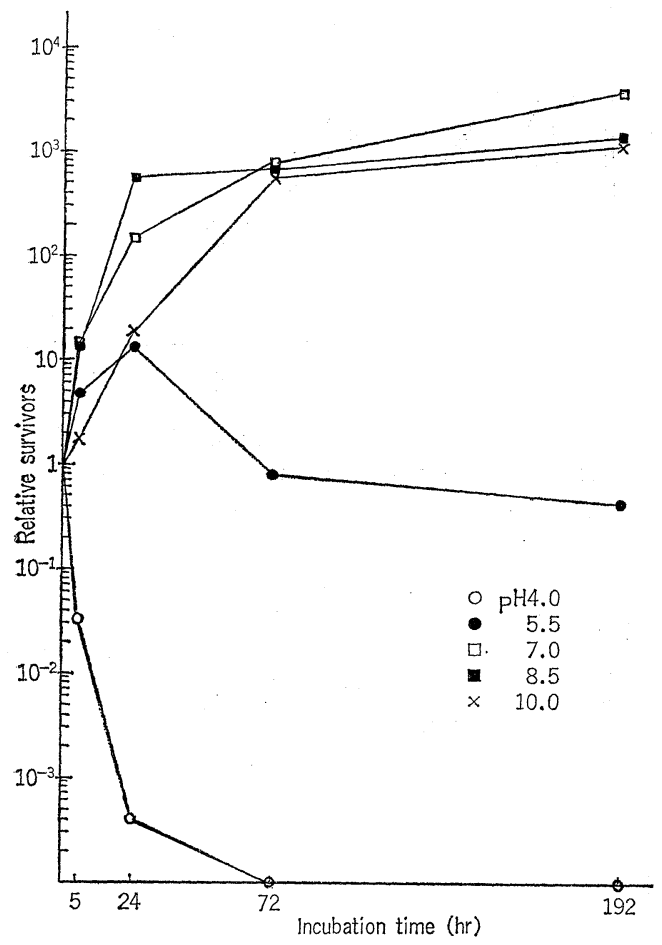

Fig. 10 Growth curves of Ps. aeruginosa in $\mathrm{M} / 10$ phosphate buffer solutions containing $5 \%$ of collagen hydrolysate

この試験液に IU を添加した場合, Fig. 11, 12 に示 すように E. coli に対しては pH 5.5 での抗菌力が大き く, pH 7.0 ではかなり小さい。また Ps. aeruginosa に 対しては各 $\mathrm{pH}$ とも抗菌力はかなり小さかった。

\section{$3 ・ 2$ E. coli に対する光毒性試験}

結果を Fig. 13 に示す。E. coli を稘濁した $0.1 \%$ IU 水溶液に $300 \sim 400 \mathrm{~nm}$ ( $20 \mathrm{~W}$ 東芝. FL20S-BLB 使用) の 紫外線照射を行なっても生存率低下はみられない。一方 290 350nm（20W 東芝 FL20SE 使用）の紫外線照射を 行ならとIU の濃度が増すに従って菌の照射生存率は低
下する。

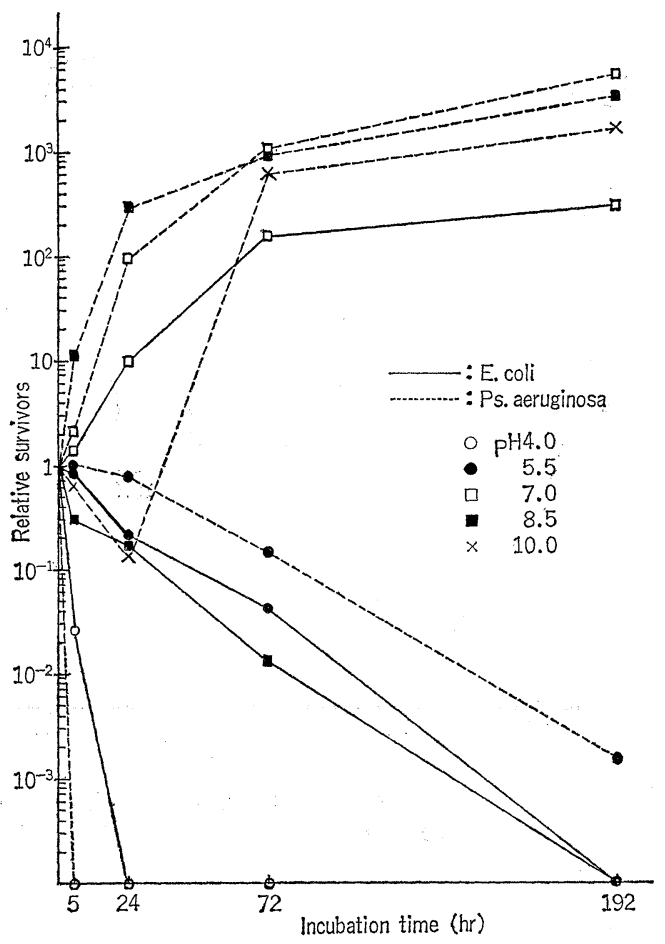

Fig. 11 Growth curves of E. coli and Ps. aeruginosa in $M / 10$ phosphate buffer solutions containing $0.025 \%$ of IU and $5 \%$ of collagen hydrolysate

一方 IUを含まない状態での $290 \sim 350 \mathrm{~nm}$ の紫外線照 射でもこの波長紫外線の細胞毒効果により照射生存率が 低下する。この両曲線の比較から IU 添加の場合の方が 無添加に比較して照射生存率の低下が大きく，290 350 $\mathrm{nm}$ の紫外線照射ではみかけ上の光毒性効果が認められ る。

\section{4 考察}

一般に抗菌剂は血液, 蛋白質 ${ }^{2}$ ，界面活性剂（特に非 イオン界面活性剂) ${ }^{3)}$, 高分子物質 ${ }^{42}$ ，等によりその抗菌 力が低下する。

IU に関する報告は現在のところ少ないが血液，蛋白 質，ミルク等の存在下でもその抗菌力の低下が此較的小 さく，また広い範囲の $\mathrm{pH}$ に於て有効であるとの報告が ある1。

本実験ではゼラチン溶液中に和沙る試験菌の生育は, コラーゲン加水分解物溶液中に拉ける生育より優れてい る。しかるにこれらの系にIUを添加した場合，抗菌力は 


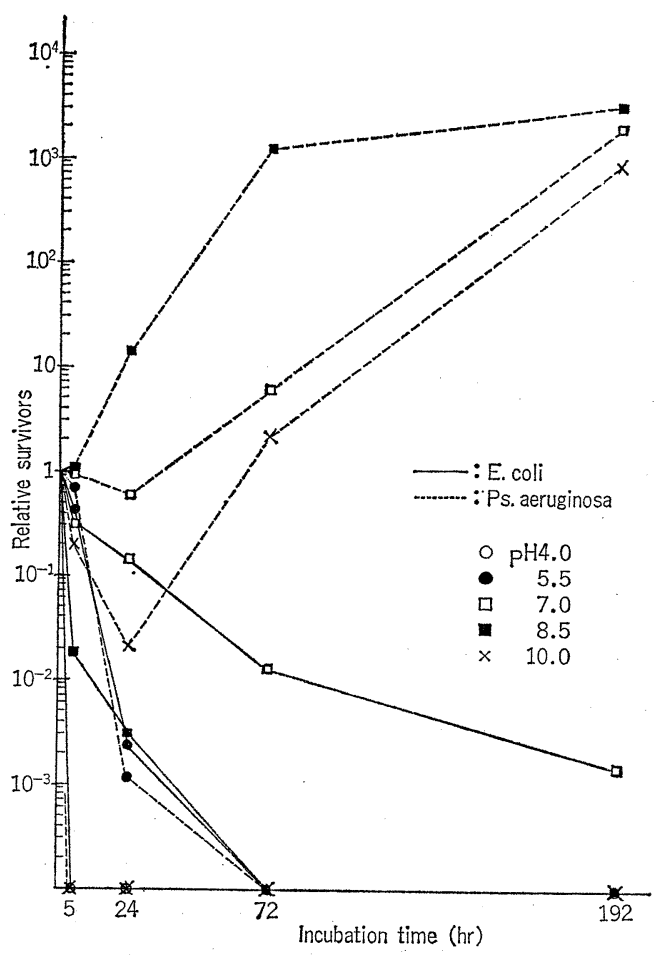

Fig. 12 Growth curves of E. coli and Ps. aeruginosa in $\mathrm{M} / 10$ phosphate buffer solutions containing $0.1 \%$ of IU and $5 \%$ of collagen hydrolysate

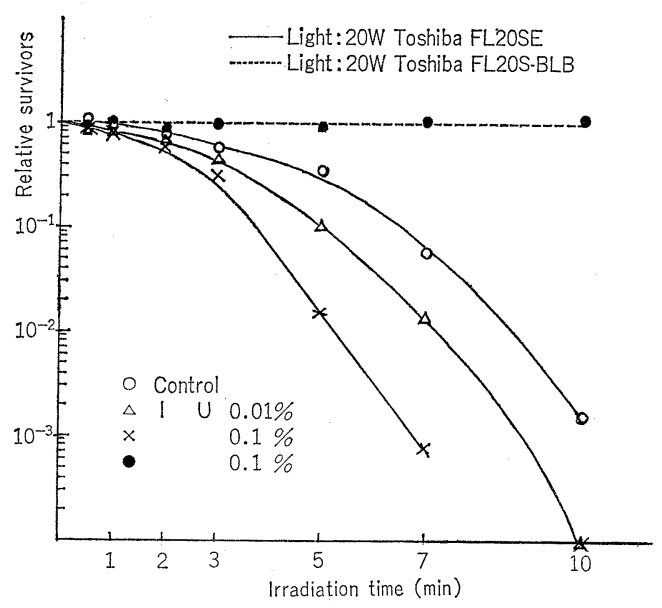

Fig. 13 Phototoxity of IU against E. coli

ゼラチン溶液中における方がコラーゲン溶液中における よりも大きい。

これは IU がゼラチンよりもコラーゲン加水分解物に 対して,より結合しやすいためであると考えられる。すな わち平均分子量はゼラチンが $61000 ６ 70000$, コラーゲ
ン加水分解物が $350 \sim 400$ であり, 従って他物質との結 合に関与する末端基の数は，ゼラチンの方がコラーゲン 加水分解物よりも少ないことからもこのことが推察され る。な和構成アミノ酸組成についてはゼラチン, コラー ゲン加水分解物ともに大きな差はないと考えられる5 。 ただ著者はこの結合に関する実験は行なっていない。

IU はリン酸緩衝液, ゼラチン添加リン酸緩衝液中で の抗菌力試験でみられるようにアルカリ側での抗菌力が 大きい。

ただコラーゲン加水分解物 $5 \%$ 添加リン酸緩衝液中 での生育至適 $\mathrm{pH}$ の範团がやや狭くなり, たた IU の抗 菌力が酸性剤でやや大きい。これはコラーゲン加水分解 物の添加が試験菌に対して幾分阻害的に作用し，それが 酸性側で IU の抗菌性との相加作用としてあらわれたも。 のと考えている。

IU の動物に対する光毒 性試験は行なっていないが, E. coli を IU の PBS 溶液中で 290〜350nm の紫外線 照射を行ない，みかけ上の光毒性が認められた。

\section{5 総括}

IU の抗菌力について E. coli, Ps. aeruginosa を使用 し, pH 及びゼラチン, コラーゲン加水分解の影響を試験 した。併せて E. coli に対する光毒性試験も行なった。 その結果, IU はアルカリ側での 抗菌力が大きい傾向 がみられた。

またゼラチンとの共存でわずかながら抗菌力の低下が みられた。コラーゲン加水分解との共存ではかなり抗菌 が低下し，特に Ps. aeruginosa に対する抗菌力はかな り低下した。ただこのコラーゲン加水分解物溶液中での 抗菌力はアルカリ側よりも酸性側でやや大さかった。

E. coli に対するみかけ上の光毒性は弱いながら認め られた。

\section{文献}

1) P. A. Berke and W. E. Rosen, American Perfumer and Cosmetics, 85, 55 (1970)

2) 加藤洋次, 高橋明, 田宮久彰, 河野通治, 霜三雄, 食衛誌, 7, 60 (1966)

3) M. G. DeNavarre and H. E. Bailey, J. Soc. Cosm. Chem., 7, 427 (1956)

4) M. D. Ray., K. E. Avis and C. C. Flarigan. Jr, J. Pharm. Sci., 57 [4] 609 (1968)

5）野田春彦, 蛋白質化学(4), P. 101 (1956)

（昭和 49 年10月 22 日受理） 